\title{
小学校の裏山の利用実態とその 活用の可能性に関する研究
}

\section{A STUDY ON ACTUAL CONDITION AND POSSIBILITY USING OF ELEMENTARY SCHOOL WITH HILLBACK}

\author{
真境名達哉—— $* 1$ 内田正徳 — $* 2$ \\ キーワード : \\ 裏山, 小学校, 山遊び, 地方都市 \\ Keywords: \\ Hillback, Elementary school, Mountain play, Local city
}

\author{
Tatsuya MAJIKINA — $* 1 \quad$ Masanori UCHIDA — $* 2$
}

There are some elementary schools that have hillbacks adjacent to themselves in local cities. We surveyed actual conditions of education and mountain play in the hillbacks in IBURI sub prefecture Hokkaido and asked the boards of education in Hokkaido about possibilities of elementary schools using hillbacks. The results became the followings.

1) $11 \%$ elementary schools use hillbacks in class. P.T.A or teachers almost maintain the hillbacks.

2) Over $60 \%$ boards of education in Hokkaido feel the elementary schools with hillbacks have possibilities, for example, for environmental education.

3) Mountain play in the hillbacks which is concerned with block plan of elementary schools or parents understanding. For example, we found much mountain play at the school with the faculty's office near the entrance in the hillbacks.
1. はじめに

小学校などの教育の場では、いわゆるエコスクールなど環境を考 慮したユニークな事例が多く見られるようになった*1。一方既往研 究では、小学校の敷地内における自然空間の整備要件の把握*2や、 自然空間として河川と小学校との関連を模索する*3など、周辺条件 の自然空間を生かした教育や遊びなどの事例が取り上げた研究が見 られるが、このように建物単体だけに依らない自然空間を生かした 小学校の計画も、今後は積極的に考えていくべきであろう。

自然空間の一つに山の持つ自然空間がある。山はその字義に「平 地より高く隆起した地塊」とある*4が、平地に比べると開発のし難 さなどから、樹木などの自然が残る場合がある。本論では、小学校 と物理的に接する山を「裹山」と称し、それを取り上げるが、裏山 が日常的な教育・学習活用の場あるいは遊び場となれば、児童にと ってはより身近な自然と触れ合う場となるはずである。「裏山を持つ 小学校」は理想的な配置条件であり、このような条件の小学校は少 ないと思われるかもしれないが、学校に関する建築計画では一般的 に、校地選定は周辺の自然環境を考慮することが求められている*5 ため、例えば大都市に比べ土地活用が厳しくない地方都市などでは、

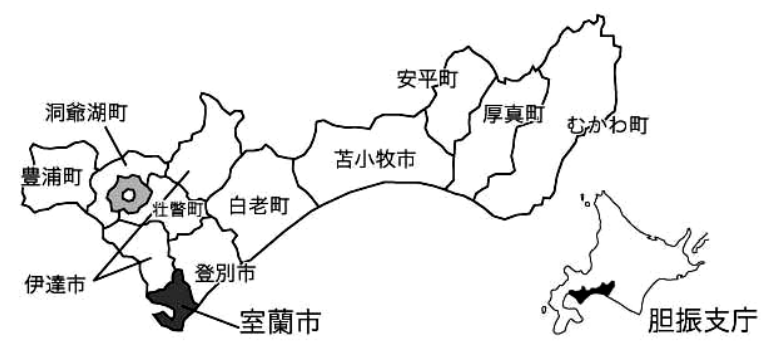

図1 北海道胆振支庁
このような条件の小学校が少なからず存在すると思われる。いずれ にせよ、このような好条件を持つ小学校があるならば、それを生か した学校つくりが学校の個性化にも繋がるだろう。

以上より本研究では、地方における一つの事例として、北海道お よび北海道胆振支庁と室蘭市を調査対象に、教育・学習の場そして 日常的な遊びの場となっている小学校の裏山の利用実態を捉える。 特に、裏山での遊びに関連した建築条件を把握し、教育委員会に裏 山活用の小学校への関心を尋ねることで、裏山を活用した小学校の 建築の可能性とそれら計画に際しての留意点を捉える。

\section{2. 研究の方法}

本研究で行った調查の概要は表 1 となる。まず図 1 の北海道胆振 支庁 11 市町を対象に、小学校の裏山の有無および、裏山での教育・ 学習などの活用の状況をアンケート調査（調査 1）より捉える。裏 山活用の小学校に関しては、11 校へ電話による活動内容等のヒアリ ングと共に 5 校（登 A、登 B、室 A、室 B、室 C) については現地調

表1 調査の概要

\begin{tabular}{|c|c|c|c|c|}
\hline & 調査名 & 日時 & 対象 & 調査内容 \\
\hline $\begin{array}{c}\text { 調 } \\
\text { 查 } \\
1\end{array}$ & \begin{tabular}{|l} 
裏山の教 \\
育アンケー \\
ト調査
\end{tabular} & $\begin{array}{l}\text { 平成 } 18 \\
\text { 年12月 }\end{array}$ & $\begin{array}{l}\text { 北海道胆振支庁98校のう } \\
\text { ち裏山に接する25校への } \\
\text { アンケート }\end{array}$ & 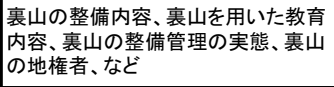 \\
\hline 調 & $\begin{array}{l}\text { 裏山の詳 } \\
\text { 細ヒアリン } \\
\text { グ調査 }\end{array}$ & $\begin{array}{l}\text { 平成21 } \\
\text { 年9月 }\end{array}$ & $\begin{array}{l}\text { 裏山を教育などで活用す } \\
\text { る11校、現地調査は5校 }\end{array}$ & 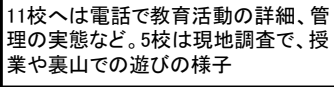 \\
\hline $\begin{array}{l}\text { 調 } \\
\text { 査 } \\
3\end{array}$ & \begin{tabular}{|l|} 
遊びに関 \\
するアア \\
ケート調査
\end{tabular} & $\begin{array}{l}\text { 平成 } 18 \\
\text { 年9月、 } \\
\text { 10月 }\end{array}$ & $\begin{array}{l}\text { 室蘭市の無作為抽出の15 } \\
\text { 校の3年生 (395名)と6年生 } \\
\text { (407名)の計802名 }\end{array}$ & \begin{tabular}{|l} 
普段遊びの場所、遊びの頻度、特に \\
山遊びの内容や時間など
\end{tabular} \\
\hline $\begin{array}{l}\text { 調 } \\
\text { 査 } \\
4\end{array}$ & $\begin{array}{l}\text { 教育委員 } \\
\text { 会へのアン } \\
\text { ケート調査 }\end{array}$ & $\begin{array}{l}\text { 平成19 } \\
\text { 年1月 }\end{array}$ & $\begin{array}{l}\text { 北海道から無作為抽出の } \\
\text { 80市町の教育委員会(回 } \\
\text { 答57市町、回収率71\%) }\end{array}$ & $\begin{array}{l}\text { 裏山を活用した学校建築への期待、 } \\
\text { 実現に対しての考慮すべき点など }\end{array}$ \\
\hline
\end{tabular}

本稿は文献 8),9) に新たな調査結果を加え、修正したものである。

室蘭工業大学くらし環境系学科 講師・博士 (工学)

（广 050-8585 室蘭市水元町 27-1）

(籼フジ夕広島支店 工修

*1 Lecturer, College of Environmental Technology, Muroran Institute of Technology, Dr. Eng.

Fujita Corporation, M. Eng. 
查を行っている（調查 2)。次に、遊びの場としての裏山に着目し、 それを可能とする条件の考察を行っている。遊びとは児童らにとっ て、より自発的な自然環境との関わりを持つ行為であることを考え る*6 と、遊び場としての裏山の条件を把握することは重要と考えた からである。遊びに関しては、室蘭市の児童を対象に、普段の遊び から山での遊びについて実態把握を行った（調查 $3{ }^{* 7}$ )。特に小学校 裏山での遊びの実態は、先の調查 2 において、現況調查および学校 管理者へのヒアリングも行っている。最終章は、全道の範囲で無作 為に抽出した教育委員会（N=80）を対象に、小学校の裏山の活動に 関してどのような考えを持つかをアンケート調査（調查 4）し、裏 山を活用した学校建築の可能性を考察する。

\section{3. 教育 - 学習の場としての裏山}

\section{3-1. 裏山および教育・学習の場の活用実態}

北海道の胆振支庁には、小学校が合計 98 校存在する（平成 19 年 3 月現在)。各市町の都市現況図を用いて、物理的に裏山に接する*8 小学校を数えると、25 校 $(26 \%)$ ある事が分かった ${ }^{* 9}$ 。それら 25 校に対し、「学校の活動（授業等）で活用しているか」の質問で裏山 の活用状況を尋衫ると、25 校中 11 校 $(44 \%)$ が裏山を活用してい た（表 2）。胆振支庁の全体としても、およそ11\%（11/98）の小学 校が裏山を活用していたことになる。

表 3 は活用のあった 11 校の利用や整備の状況を示したものである。 表より裏山の整備内容を見ると、まず全てが「散策路」をもってい る（11 校）が、現地調查した 5 校を見ると、その多くがけものみち 程度の細い道であった。その他「樹木名札」が 5 校、「ロープ」など の簡単な遊具から「アスレチック遊具」が合わせて 4 校程度あるほ か、「(野鳥用の) 鳥小屋」を設置している学校もある。

裏山を用いた授業では、「生活」「総合的な学習の時間」「理科」が

表2 北海道胆振支庁における裏山活用校

\begin{tabular}{|c|c|c|c|c|c|c|c|c|c|c|c|}
\hline $\begin{array}{l}\text { 市 } \\
\text { 町 } \\
\text { 名 }\end{array}$ & $\begin{array}{l}\text { 学 } \\
\text { 校 }\end{array}$ & $\begin{array}{l}\text { 活 } \\
\text { 用 }\end{array}$ & $\begin{array}{l}\text { 児 } \\
\text { 童 } \\
\text { 数 }\end{array}$ & $\begin{array}{l}\text { 市 } \\
\text { 町 } \\
\text { 名 }\end{array}$ & 学 & $\begin{array}{l}\text { 活 } \\
\text { 用 }\end{array}$ & $\begin{array}{l}\text { 児 } \\
\text { 童 } \\
\text { 数 }\end{array}$ & $\begin{array}{l}\text { 市 } \\
\text { 町 } \\
\text { 名 }\end{array}$ & $\begin{array}{l}\text { 学 } \\
\text { 校 }\end{array}$ & $\begin{array}{l}\text { 活 } \\
\text { 用 }\end{array}$ & $\begin{array}{l}\text { 児 } \\
\text { 童 } \\
\text { 数 }\end{array}$ \\
\hline 發吵 & 登A & 0 & 297 & \multirow{4}{*}{ 室蘭 } & 室F & $x$ & 155 & 厚真 & 厚D & $x$ & 26 \\
\hline 豆 & 登B & 0 & 224 & & 室G & $x$ & 133 & \multirow{4}{*}{ 豊浦 } & 豊A & 0 & 29 \\
\hline 伊達 & 伊A & $x$ & 42 & & 室H & $x$ & 130 & & 豊B & $x$ & 2 \\
\hline 苫小牧 & 苫A & 0 & 76 & & 室I & $x$ & 84 & & 豊C & $x$ & 8 \\
\hline \multirow{5}{*}{ 室蘭 } & 室A & 0 & 142 & 白老 & 白 $\mathrm{A}$ & $x$ & 319 & & 豊D & $x$ & 3 \\
\hline & 室B & 0 & 153 & 安平 & 安A & $x$ & 196 & 洞爺湖 & 洞A & 0 & 8 \\
\hline & 室C & 0 & 41 & \multirow{3}{*}{ 厚真 } & 厚A & $x$ & 144 & 壮瞥 & 壮A & $x$ & 49 \\
\hline & 室D & 0 & 30 & & 厚B & 0 & 80 & \multirow{2}{*}{\multicolumn{4}{|c|}{$\begin{array}{c}\text { 凡例) 活用あり: O } \\
\text { 活用無し: }\end{array}$}} \\
\hline & 室E & $x$ & 99 & & 厚C & 0 & 16 & & & & \\
\hline
\end{tabular}

それぞれ 6 校と多く、「図画工作」で 3 校、「体育」「国語」でそれぞ れ 2 校の利用となっている。例として室 B の学習要項を見ると（表 4)、1 年の生活の授業から利用しており、積雪期を除き利用されて いる。また登 $\mathrm{A}$ を除くヒアリング 4 校がそうであったが、裏山への 移動時間が短く、学外移動の届け出も提出しなくてもよいので、必 要があれば授業の間に行き来していた。また室 B は生活科目や総合 的な学習時間など横断的な科目において、特に裏山は利用しやすい と述べていた。

平成 18 年時のヒアリング調査では、 6 年生の歴史の時間に堅穴式 住居を 10 日間かけてつくるなどの事例があった（室 A）が、平成 21 年の調查（調查 2）では見られなかった。ヒアリングした 5 校によ ると、カリキュラム内容は担当教員の計画に依るので、結果として よく用いる年もあれば余り用いない年もあり、学校として「裏山を 積極的に利用する」などの指導はないようである。

\section{3-2. 教育・学習の場の管理}

裏山の地権者をみると（表 3）、4 校は「民間」でその他の 7 校は 「市町および学校」の保有となっているが、現地調査で訪ねた所で は、敷地境界が明確にあるわけではなかった。裏山の整備では、 5 校がその実施者に「PTA」を挙げている。また整備の予算では 5 校が 「PTA ないし学校」からの予算が組まれていた。例えば、アスレチ ック遊具が充実している室B などは、約 20 年もかけ継続的に増設し ながら設置していた。また特に予算が組まれていない学校において も、管理では教員も含めPTA が管理機材を持ち出し、草刈りなどを

表4 裏山を用いた授業(室Bの事例)

\begin{tabular}{|c|c|c|c|c|c|}
\hline 1年 & & & & & \\
\hline 科目:生活 & 月 & 時間 & 科目:図工 & 月 & 時間 \\
\hline 校庭探検 & 5 & 2 & 触ってかんじる & & 2 \\
\hline 春の野原、生き物遊び、他 & 6 & 10 & & & \\
\hline 秋の野原、いろいろな花や実 & 10 & 10 & & & \\
\hline 秋の宝物大会、他 & 11 & 10 & & & \\
\hline 冬の野原、冬の生き物探し & 12 & 4 & & & \\
\hline 2年 & & & & & \\
\hline 科目:生活 & 月 & 時間 & & & \\
\hline しっている不思議、他 & 5 & 8 & & & \\
\hline 生き物紹介、もつと知りたい、他 & 9 & 6 & & & \\
\hline 3年 & & & & & \\
\hline 科目: 理科 & 月 & 時間 & 科目:総合 & 月 & 時間 \\
\hline 出かけよう自然の中へ & 7 & 2 & 裏山探検 & $5 \backsim 11$ & 14 \\
\hline 昆虫を探そう & 9 & 5 & & & \\
\hline 4年 & & & & & \\
\hline 科目:理科 & 月 & 時間 & 科目:総合 & 月 & 時間 \\
\hline 春の自然 & 5 & 9 & 裏山探検 & $5 \sim 11$ & 14 \\
\hline 夏の自然 & $7 \backsim 8$ & 2 & & & \\
\hline 秋の自然 & 10 & 4 & & 間を裏山 & 山で費 \\
\hline 冬の自然 & 12 & 4 & & bけでは & よない \\
\hline
\end{tabular}

表3 裏山活用の状況

\begin{tabular}{|c|c|c|c|c|c|c|c|c|c|c|}
\hline \multirow{2}{*}{ 市町 } & \multirow{2}{*}{ 学校 } & \multirow{2}{*}{$\begin{array}{c}\text { 児童 } \\
\text { 数 }\end{array}$} & \multirow{2}{*}{ 裏山の整備内容 } & \multicolumn{2}{|c|}{ 裏山を用いた授業 } & \multicolumn{3}{|c|}{ 整備・管理 } & \multirow{2}{*}{$\begin{array}{l}\text { 裏山の } \\
\text { 地権者 }\end{array}$} & \multirow{2}{*}{$\begin{array}{l}\text { 裏山の日常的 } \\
\text { な遊び利用 }\end{array}$} \\
\hline & & & & 授業内容 & 授業で用いる頻度 & 整備者 & 予算 & 整備管理頻度 & & \\
\hline \multirow{2}{*}{ 登別 } & 登A & 297 & 散策路·ロープ・樹木名札 & 生活·理科·総合 & 夏·秋·冬に数回 & PTA·地域住民 & PTA & 年に数回 & 民間 & 無 \\
\hline & 登B & 224 & 散策路·アスレチック & 図エ・スキー & 年30回くらい(スキー) & \begin{tabular}{|l|} 
PTA-教職員 \\
\end{tabular} & 無 & 年2回ほど & 市 & たまに利用 \\
\hline 苫小牧 & 苫A & 76 & 散策路 & 生活·総合 & 年間数回 & 地域住民 & 学校 & 年に数回 & 学校 & 無 \\
\hline \multirow{4}{*}{ 室蘭 } & 室A & 142 & 散策路·樹木名札 & 生活·図エ·理科·総合 & 春·夏·秋に数回 & 無 & 無 & 無 & 市 & 上<利用 \\
\hline & 室B & 153 & 散策路·樹木名札·ロープ·鳥小屋·アスレチック & 生活·図工·理科·総合 & 春·夏·秋に数回 & PTA-教職員 & PTA & 毎週 & 学校 & よく利用 \\
\hline & 室C & 41 & 散策路·樹木名札·案内看板 & 理科·国語 & 春·夏·秋に頻繁、冬に数回 & 用務員 & 学校 & 月1回 & 学校 & たまに利用 \\
\hline & 室D & 30 & 散策路·ロープ•アスレチック·案内看板 & 生活·図エ·クラブ & 春·夏·秋に数回 & PTA & PTA & 年1回 & 学校 & たまに利用 \\
\hline \multirow{2}{*}{ 厚真 } & 厚A & 80 & 散策路 & 生活·理科·総合 & 春先に数回 & PTA·教職員 & 無 & 年1回 & 民間 & 無 \\
\hline & 厚B & 16 & 散策路 & 理科·国語 & 年間数回 & PTA & 無 & 年1回 & 民間 & よ<利用 \\
\hline 富浦 & 豊A & 29 & 散策路·樹木名札 & 総合 & 年間数回 & PTA & 無 & 年1回 & 町 & 無 \\
\hline 洞爺湖 & 洞A & 8 & 散策路 & 総合·体育 & 春·秋·冬に数回 & 無 & 無 & 無 & 民間 & 無 \\
\hline
\end{tabular}


おこなっていた。裏山の整備はほとんどの学校が「年 1 回」以上行 っており (9/11)、ヒアリングから春先に 1 回目が行われている。そ の内容は倒木の伐採・除去、草刚りそして安全確認となっている。

ヒアリングで安全管理の注意点を尋ねると、真っ先にあげるのは 「倒木」の確認 $(4 / 5)$ で、実際に倒木により怪我をした生徒がいた （登A）他、目の前で大きく倒木した学校もあった（室 A、室B）よ うで、各校強く注意を払っているという印象を受けた。また、登 $B$ 以外の全ての学校では、学校管理者が直接裏山に入り倒木の状況な どを確認していた。その他、ヒアリングの 5 校が全て「まむし、八 チ、ダニなどの害虫」、および「ツタ漆」への注意を促しており、他 には「雨の日は滑るので注意：室 A」、「キッネを触らない（エキ） コックスへの注意）：室 A」、「鳥の死骸を触らない（鳥インフルエ ンザ対策）：室 B」などの注意を促す学校もあった。ヒアリングか ら、各校とも安全管理に関し、児童への注意を促すなどの点で学校 管理者の負担が窥えたが、安全管理に関する予算面や労力面では、 大きな不満の声は聞かれなかった。

\section{4. 遊びの場からみた山}

\section{4-1. 普段の遊び}

遊び場としての裏山をみる前に、調查地の児童にとって山はどの ような遊び環境なのかを捉える。表 5 は室蘭市の児童を対象にした 調査 3 のアンケートの結果概要である。まずは普段遊びから見ると、 放課後の遊び時間は平均 1.8 時間、平均 4.4 人程度で遊んでいる。 また約 $70 \%$ 近い児童が習い事をしており、約 $90 \%$ がゲームを所有し、 その遊びに 1 日に 1.6 時間も費やしている。遊びの場所とその遊び 頻度を尋㸚たところ（図 2）、「週 1、2 回以上あそぶ」では「自分や 友達の家」が最も多く $80 \%$ 、「家の周辺」で $68 \%$ 、「公園」で $59 \%$ と続いており、「山」での遊びは「週 1、2 回以上あそぶ」で $20 \%$ と図 2 の項目中最も低い值となっている*10。

\section{4-2. 山遊び}

山での遊びに関するアンケート結果は、図 3 と表 6 に詳しく

表5 遊びと遊び関連の概要 (室蘭市)

\begin{tabular}{|c|c|c|}
\hline \multirow{2}{*}{ 放課後の遊び } & 平均遊び時間(回答: 744) & 1.8時間 \\
\hline & 遊びの平均人数 (回答: 789) & 4.4人 \\
\hline \multirow{2}{*}{ 習い事 } & 習い事をしている割合(回答: 795) & $69 \%$ \\
\hline & 習い事の平均数(回答: 548) & 2.9回／週 \\
\hline \multirow{2}{*}{ ゲーム } & ゲームの所有割合 (回答: 800) & $88 \%$ \\
\hline & ゲームの時間(回答: 675) & 1.6時間 \\
\hline \multicolumn{2}{|r|}{ 自室の所有(回答: 767) } & 専用 $(49 \%)$ 、兼用 $(38 \%)$ 、なし $(12 \%)$ \\
\hline
\end{tabular}

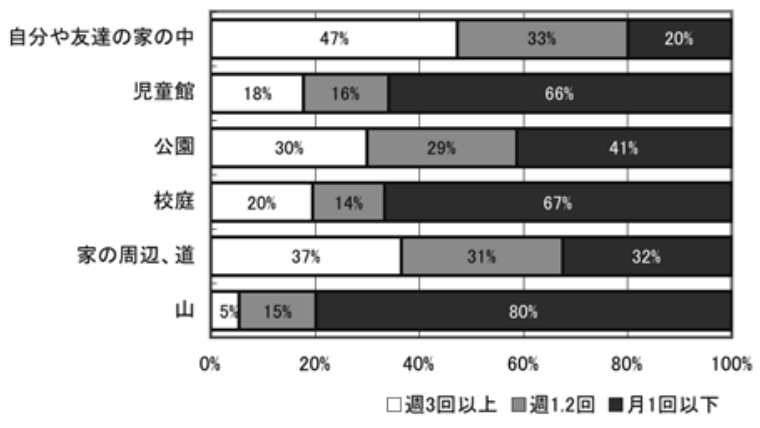

図2 普段遊びの場所と頻度( 室蘭市)
まとめた。まず図 3 を見ると、山遊びの内容としては、「探検」(50\%) をはじめ「秘密基地」遊び（39\%)、「虫・生き物とり」（39\%）など 多くの種類の遊びが見られたほか、表 6 より半数は 1 時間以上山遊 びを行っている $(50 \%)$ 。山遊びの嗜好では「大好き・好き」と「好 きではない・嫌い」の割合は、それぞれ $50 \%$ となっていた*11。な お、嗜好の理由もアンケートの自由記述で尋㸚たが、特に「好きで はない・嫌い」の理由として、虫の存在を挙げる者が多かった（自 由記述で $51 \%$ ) *12。

表 6 より山への移動手段を尋㸚ると「徒歩」「自転車」があわせて $80 \%$ を占めており、アンケートで申告されたその平均移動時間は「徒 歩」18 分 $(\mathrm{N}=290)$ 、「自転車」 14 分 $(\mathrm{N}=99)$ となっていた。これら から対象地では、山は物理的には児童らの居住環境からそれほど遠 くないことが窥える。しかし、一方で「山遊びは何をするかを決め てから遊んでいる」場合が $42 \%$ 、「初めての山遊びでも親・大人と 同伴して入る」場合も $38 \%$ あることを考えると、全体としては必ず しも気軽に山で遊んでいない様子が窥われた。

\section{5. 裏山での遊びの条件}

前章で見たように、対象地を見る限り必ずしも山遊びが気軽に行 われているわけではないが、各小学校の単位で見た場合では、山遊 びが多く行われている小学校が存在する（図 4)。室A、室 B は「月 1、2 回以上遊ぶ」で $80 \%$ 程度となっており、他の小学校に比べ高い 值を示している。先の表 3 の「裏山の日常的な遊び利用 (はあるか)」 の質問にも、学校管理者は「よく利用（しているようだ）」と答えて いることから、図 4 で小学校毎にみる山遊びの多さには日常的な裏 山遊びの多さが関連していることが窥える。一方で表 3 の他の項目 を見ると、日常的な遊び利用が「たまに利用」「無」の学校も 11 校 中 8 校見られる。よってここでは、「よく利用」の室 A、室B、「たま

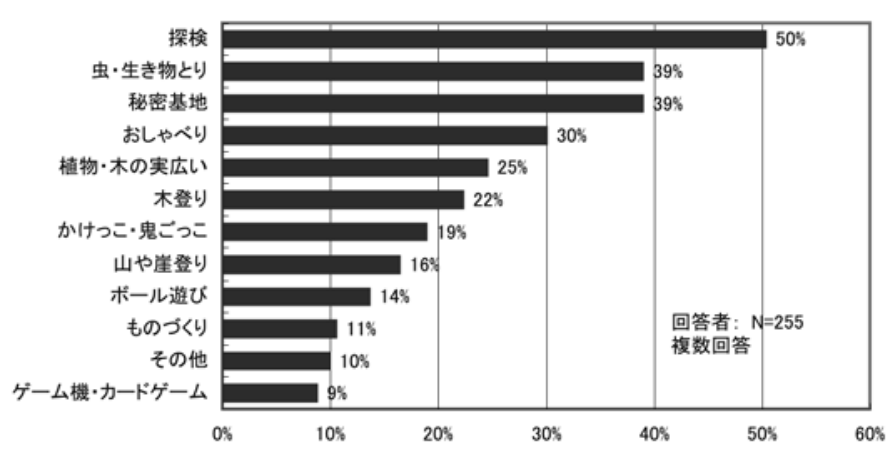

図3 山遊びの内容( 室蘭市)

表6 山遊びの概要 (室蘭市)

\begin{tabular}{|c|c|}
\hline $\begin{array}{l}\text { 山への移動手段 } \\
\text { (回答: 744) }\end{array}$ & 徒歩 (59\%)、自転車 (20\%)、車(19\%)、バス(2\%): 計100\% \\
\hline $\begin{array}{l}\text { 初めての山遊び同伴者 } \\
\text { (回答: } 508)\end{array}$ & $\begin{array}{l}\text { ひとり (4\%)、上級生 (13\%)、同級生 (36\%)、下級生 (7\%)、親· } \\
\text { 大人 }(38 \%) 、 \text { 他 }(3 \%) \text { : 計 } 100 \%\end{array}$ \\
\hline $\begin{array}{l}\text { 山遊びの嗜好 } \\
\text { (回答: 792) }\end{array}$ & $\begin{array}{l}\text { 大好き (22\%)、好き (28\%)、好きではない(25\%)、嫌い(25\%)： } \\
\text { 計 } 100 \%\end{array}$ \\
\hline $\begin{array}{l}\text { 山遊びの時間 } \\
\text { (回答: 255) }\end{array}$ & $\begin{array}{l}\text { 15分ほど(24\%)、30分ほど(26\%)、1時間ほど(18\%)、1時間半 } \\
\text { ほど(15\%)、2時間ほど(17\%): 計100\% }\end{array}$ \\
\hline $\begin{array}{c}\text { 山遊びを決めるまで } \\
\text { (回答: } 254)\end{array}$ & $\begin{array}{l}\text { 山で何をするか決めて (42\%)、山に行くことは決めて何をするか } \\
\text { は決めない }(36 \%) 、 \text { 、らつと気軽に(22\%)、:計100\% }\end{array}$ \\
\hline
\end{tabular}




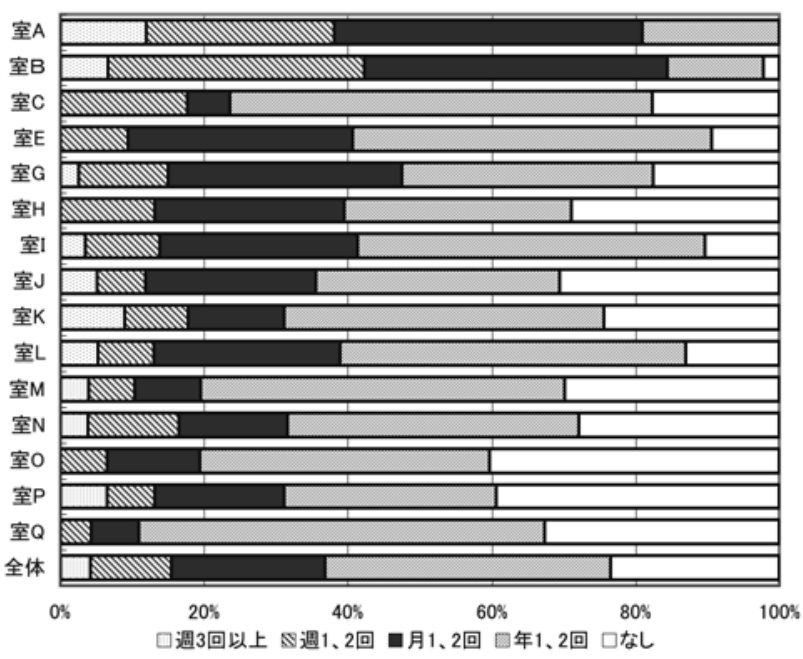

図4 小学校単位でみた山遊びの頻度 (室蘭市)

に利用」の登B、室C、「無」の登 A 5 校を実際に尋ね、特に裏山 での遊びがよく見られる事例についてその条件を考察する。

\section{5-1. 校舎などの配置}

図 5 は、ヒアリングを行った 5 校の裏山と校舎などの配置図であ る。まず小学校敷地における裏山の散策路の配置からみると、室 C のように運動場に近く並行し設置されたものは、運動場へ声が届く のに対し、登 $A 、$ 登 $B 、$ 室 $A$ 、室 $B$ では、校舎や運動場からかなり離 れて続く散策路となっている。5 校の裏山の斜面も全体的に緩やか ではなく、登 B のスキー場の部分を除き、多くは 10 メートル程の樹 木で覆われている。奥へと進むと校舎が見えず、声も届かない深い 散策路もある*13。これら散策路自体に不安に持つ児童がいると思わ れるが、加えて登 A、登 B は、体育館が死角になり校舎入り口や教 室からも目に触れない場所に裏山入口があるなど、児童にとっては 日常的に親しみが持てない配置となっている。

職員室と裏山入口の関係を見ても、登 A、登B は職員室から全く
目の届かない所にあり、管理面では好ましくない配置であることが 分かる。実際、現地調査では充実した散策路を持つことが分かった 登Aではあったが、裏山での遊びは届け出が必要で、ヒアリングし た 5 校中唯一、教師同伴の教育・学習の利用においても、学校管理 者に簡易な書面提出の規則を設けで*14おり、実質的にはこれらの規 則が日常的な遊び利用の「無」につながっていると思われる。一方、 運動場を挟んでいるが職員室から裏山入口がよく見える室 A、裏山 の入口が職員室の正面に位置している室 B、そして裏山全体が容易 に見える室 C は休み時間と放課後においても、遊び利用に制限を設 けていなかった。3 校とも学校管理者は裏山の遊びに関しては安心 と評価していたが、特に室 B の現地調査では（写真）、裏山入口が校 舎から裏山入口が近いこともあり、授業間の短い休み時間にも関わ らず、そこでは低学年が活発に遊んでいる様子が確認された。

\section{5-2. 裏山遊びへの寛容さ}

裏山が日常遊びで「よく利用」されるには、職員室や教室などと の配置関係が関連しているなどが窺えるが、「よく利用」されるもう 一つの要因として、父兄と教員らによる裏山の遊びへの寛容さがあ ると思われる。

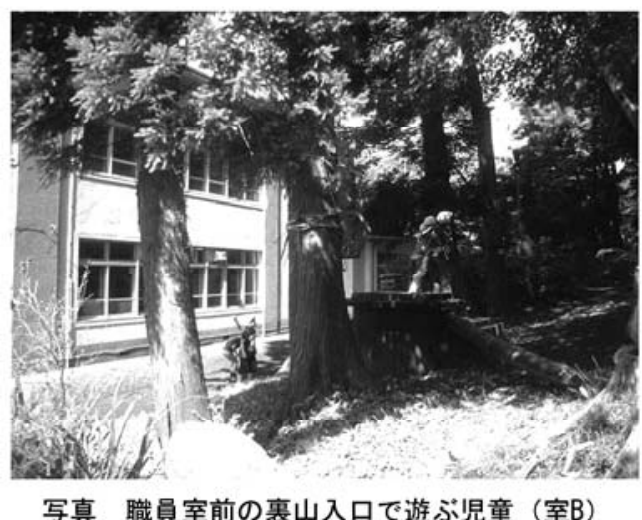

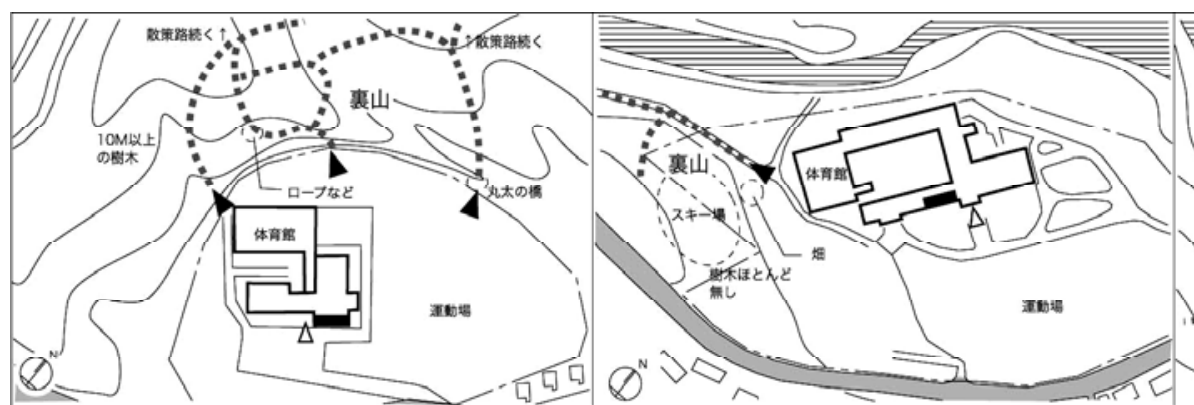

$$
\text { a) 登A }
$$

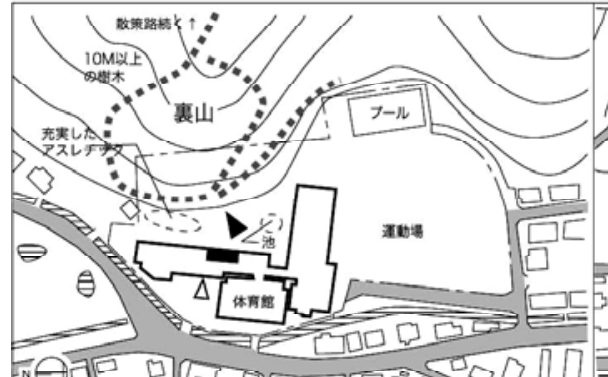

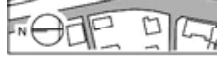

b) 登B

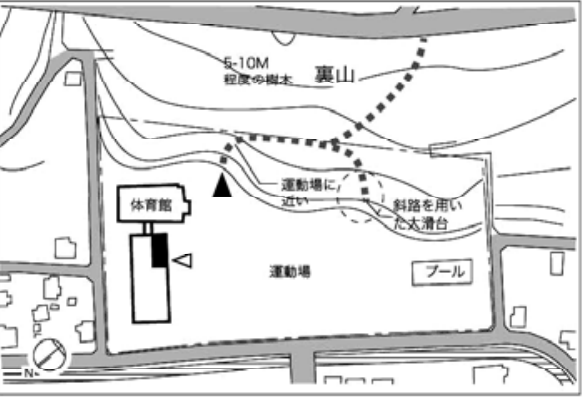

e) 室C

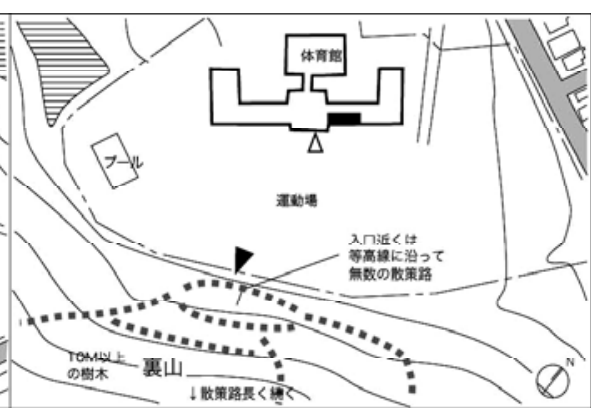

c) 室A

凡例)

裏山入口: $\boldsymbol{\Lambda}$

散策路: •*•..*

校舎入口: $\triangle$

職員室 :

アスレチック

などの場所： ‘' スケール: 0

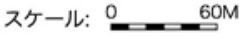

d) 室B 
ヒアリングから、室 $\mathrm{A} 、$ 室 $\mathrm{B}$ の小学校には、親子 $2 、 3$ 代に渡り同 じ小学校に通う者がいることが分かった。学校管理者の一人（室A） もこのような裏山の小学校の出身者だった*15が、話からは教員と父 兄らの間には、裏山での遊びなので「八チやダニなどには刺される こともある」といった前提があるようだ。例えば児童が八チに刺さ れた場合でも、定期的な見回りで八チの巣の除去をしていた、ある いは刺されてもすぐ巣を除去していたならば、八チに刺されたこと 自体に抗議する親はほとんどいないとのことであった。

一方室 Aでは、同時に児童には「八チの巣にいたずらしない」な ども指導していた。例えば、ヒアリングの 1 週間前に室 A の付近に マムシが出るという騒ぎがあったが、「裏山に入るな（禁止）」では なく、「へビをいじめるな」「へビがいたら先生に知らせる」という 指導を徹底していた。室 A の管理者曰く、1 年生でもちゃんと説明 寸れば、これらを守ることができ、そうすれば裏山での（大きな） 問題は生じないとのことである。その他、室 B においても、裏山入 口近くの（観察用の）池に落ちた児童を「3 代続けて落ちた」と笑 い飛ばす親の話など、少々の失敗や怪我は山遊びでは生じるものと いった寛容さを室A、室Bの小学校では窺うことができた。

\section{6. 教育委員会からみた裏山への関心}

最後に行政側から、裏山の活用をどう考えているかを探った。北 海道内の 15 歳未満人口 500 人以上の市町の中から無作為に約半数と なる 80 市町の教育委員会を選定し、裏山を活用した学校建築につい ての意識をアンケートで尋ねた。アンケートの内容は、各市町で取 り組んでいる、または取り組みたい環境教育などのプログラムと裏 山を活用した学校建築への興味などである。

「小学校の建て替え、改修の機会に裏山を活用した環境教育と学 校建築について考えたいか」の回答では、図 6 より「積極的に考えた い「考えたい」が全体の $67 \%$ となっていた。なお「興味がない」の理 由には、「裏山が少ない」通学に不便」「統廃合が進められ市街地一力 所に集められる傾向がある」「財政的に難しい」な゙があった。

さらに図 7 より「考えたい」と答えた中で、実現に向け考慮する条

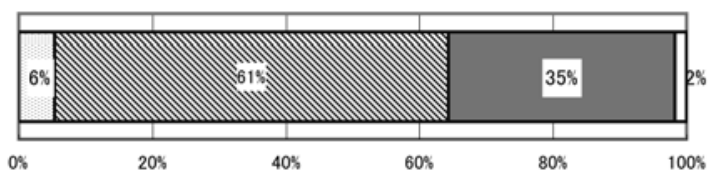

ロ積極的に考えたい $\mathbb{E}$ 考えたい ロあまり興味がない ロ興味がない

\section{図6裏山活用への関心}

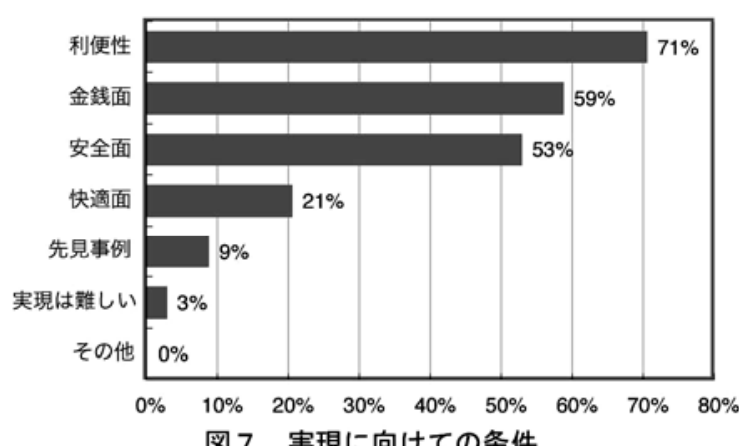

図 7 実現に向けての条件
件としては「裏山までの近さ」や「使いやすさ」などの利便面（71\%) が最も多く、「イニシャル・ランニングコスト」などの金銭面 (59\%)、 「不審者」、「ケガ」などの安全面 $(53 \%)$ と続く。また「いくら条件を 満たしても実現するには難しいとの答えが $3 \%$ みであったこと を考えると、裏山を活用した学校建築への行政側の関心は高いとい える。

\section{7. まとめ}

教育委員会の回答からも、今後環境教育への関心などから、裏山 を積極的に活用寸る小学校が増えていく可能性はあると思われる。 調査から見たように、教育・学習の場としての裏山は授業時間内の 容易な移動、様々な授業の連携などの長所があり、教員などのアイ デアによっては、よりユニークな教育の広がりが期待できると思わ れる。一方で、裏山の管理においては倒木などに関して十分な注意 を払うと共に、PTA などとも協力関係を保つなどの労力が必要にな るであろう。

また、本報では特に山での遊びにも着目したが、山に物理的に近 い本調查地において、そもそも山での遊びが少なかったこと、また 裏山を教育・学習の場として用いている学校においても、日常的な 遊びで利用される学校は必ずしも多くなかった。しかし、少数では あるが、裏山での遊びが多く見られた学校もあり、そこでは裏山入 口が職員室より容易に管理が行えるなどの条件が把握できた。裏山 での遊びが生じるためには、裏山入口の配置などには留意すべきで あろう。また、裏山での遊びに関する教員や父兄らの理解も、必要 な条件になると思われる。これらに関しては、裏山での遊びを持つ 小学校関係者を交えたワークショップを設けるなど、裏山の物理的 な環境整備だけはなく、裏山遊びに関する知識を伝える場も同時に 設けるべきであるう。

本研究では取り上げなかったが、裏山の利用は児童の良い思い出 につながるなど、学習環境をはじめ児童の生活環境をより豊かにす る空間の質が他にもあるはずである。今後は本報の分析の深化を図 ると共に、これらも積極的に見つけていきたい。

\section{謝辞}

調查に協力して頂きました各局の教育委員会、学校関係者、そし てアドバイスを頂きました建築設計事務所の皆さんに感謝申し上げ ます。

注

1）例えば、文 1 のpp83-85 では、現在のエコスクールの動向が紹介されて いる。

2）文 2 は自然空間の整備要件を網羅的に捉えている。

3) 文 3 では、自然空間である河川について、小学校による活用の取り組み が一部紹介されている。

4）文 4 による。

5 ）例えば、文 5 の pp102-107「校地選定の条件」では、隣接地が優れた自 然環境ならばそれを取り込むなどの検討事項が記されている。

6 ）览童における遊びの重要性を説く文献は多い。例えば、藤本は文 6 で「遊 びが運動能力や体力の養成、知的・精神的発達にもつ意味は大きい (p11)」とし、戸外空間での遊びの意味として「新しい意味の発見、想 像、そして挑戦といった子どもの基本的要求にうったえる（p53）」こと を挙げている。

7 ）抽出した小学校の 3 年生と 6 年生の児童全員を対象にした。欠席を除く 全員からアンケートを回収した。

8 ）都市現況図からは、小学校に隣接し建築物がなく、等高線が記された地 形で、樹木などの地図記号があるものを「裏山」として抽出した。

9 ）なお、学校の持つ自然空間として学校林がある。学校林については、全 国の学校を対象に、定期的な悉皆調査が行われている。例えば、文 6 な ぞでその学校林活動の概要が紹介されている。なお、北海道緑化推進委 
員会からの資料によると、2001 年調査では北海道胆振支庁の小学校で 9 つが学校林を持っていたが、本調査の 25 校では 2 校のみがそれらに該 当していた。

10）筆者らは文 10 で、室蘭市の小学校 3 校を対象に、写真投影法から遊び 場の特定を行ったが、その時も自然空間での遊びは出現した写真データ のおよそ $5 \%$ と少ない割合を占めた。

11）例えば山遊びの嗜好に関して 3 年生と 6 年生の学年差はほとんど見られ なかった。一方で「(山遊び) 大好き・好き」では男子 $56 \%$ に対して、 女子 $37 \%$ となっていたことから、男女差はあるようだ。

12）「大好き・好き（N=395）」のなかで中の存在がその理由として举げた归 童は 87 名、「好きではない・嫌い（N=397）」では203名がその理由に虫 の存在を挙げた。なお「嫌い」と答えた者 196 名のうち 121 名が自由記 述で、嫌いな理由として虫を挙げていた。

13） 10 分以上も続く散策路があるが、夕方にはかなりうっそうとした雾囲気 となる。

14）その他の 4 校は、教師同伴での教育・学習の利用において、口頭のみの 報告を学校管理者へ行っている。

15）室 A の校長は室 B の出身で、また室 C は彼の前任校であり、裏山の遊び はよく理解していた。ヒアリングした室 A、室 B、室 C の管理者は一棣 に裏山での少々のトラブルには寛容的だったが、これらの寛容さは教育 委員会単位で、集団的な知識として保持されているように感じられる (なお、室 Aの校長によると、特に教育委員会の連携協議会などで、裏 山活用に関する議題は無いらしい)。

逸話としては、他県出身の室 B の教頭は、初めて裏山のある小学校（室 B) に赴任したが、最初は児童の怪我を心配していた。しかし地域の寛 容さにも触れて、今では裏山での遊びを大変肯定していると述べてい た。このような経験を通じて、学校管理者の裏山への理解が集団的に保 持されるのではないだろうか。
文献

文 1）長澤悟監修『現代学校建築集成』、学事出版、2008

文2）斎尾直子、藍澤宏、他、公立小学校敷地内における自然空間の設置と 使われ方らかみた屋外空間整備に関する研究

日本建築学会計画系論文集第 544 号 pp131-138, 2002.4

文 3）畔柳昭雄、田中郁臣、都市小河川の環境整備が行政・住民・小学校に 及ぼす影響と三者の役割

日本建築学会計画系論文集第 553 号 pp253-260, 2002.3

文4）新村出 編集『広辞苑』岩波書店、1998

文 5）日本建築学会『学校建築 計画と設計』日本建築学会、1979

文 6）藤本浩之輔、子どもの遊び空間、NHK ブックス、1977

文 7）竹本太郎・奥山洋一郎・永田信 (東大農)『森林環境教育に向けた新 しい学校林づくり』日本林学会会報 No37 $7 p 39-45$ 2003.2

文 8）井上俊行、内田正徳、真境名達哉、山際を持つ地域の遊び環境と環境 教育からみた学校建築の可能性その 1 児童あそびの実能 日本建築学会学術講演梗概集、E-1 pp425-426, 2007.8

文 9）内田正徳、井上俊行、真境名達哉、山際を持つ地域の遊び環境亡環境 教育からみた学校建築の可能性その 2 学校の裏山での活動事例を 通して、日本建築学会学術講演梗概集 E-1 pp427-428, 2007.8

文 10）内田正徳、真境名達哉、写真投影法から捉えた室蘭市の子どもの遊び 場調査、日本建築学会北海道支部研究報告集 No.78 pp215-218, 2005.7

[2009 年 10 月 20 日原稿受理 2010 年 1 月 8 日採用決定］ 